\title{
Indirect effects of fish cage aquaculture on shallow Posidonia oceanica seagrass patches in coastal Greek waters
}

\author{
Konstantine J. Rountos ${ }^{1, *}$, Bradley J. Peterson ${ }^{1}$, Ioannis Karakassis ${ }^{2}$ \\ ${ }^{1}$ School for Marine and Atmospheric Sciences (SoMAS), Stony Brook University, Stony Brook, New York 11794-5000, USA \\ ${ }^{2}$ Marine Ecology Laboratory, Biology Department, University of Crete, PO Box 2208, 71409 Heraklion, Crete, Greece
}

\begin{abstract}
Over the last 3 decades fish cage aquaculture has increased exponentially in the eastern Mediterranean Sea and has induced various levels of environmental change in coastal waters. The most apparent negative changes involve the degradation of the native seagrass Posidonia oceanica (L.) Delile. Our study examined the effects of fish cage aquaculture on seagrass health, sea urchin density and herbivore feeding pressure in shallow seagrass patches in the coastal waters of 2 Greek islands (Evia and Crete) between February and May of 2008. Evia and Crete represent a wide range of fish farming intensities, from small-scale $\left(75 \mathrm{t} \mathrm{yr}^{-1}\right)$ to large-scale $(1000 \mathrm{t}$ $\mathrm{yr}^{-1}$ ) fish production, respectively. On both islands, the seagrass variables, shoot productivity, standing crop and leaf morphometrics (length and width) were significantly lower $(p<0.0001)$ in impacted seagrass patches adjacent to fish farms compared with control patches. In addition, significantly higher sea urchin densities and herbivore feeding pressure (percentage of shoots with herbivore grazing scars) were found in impacted patches on both islands. Higher leaf tissue nitrogen and epiphyte loads were also found in impacted patches, but these increases could not be attributed to fish farming alone. Our results show that negative effects on seagrass patches can occur as a result of fish farming at both small-scale and large-scale intensities and that increased sea urchin densities and feeding pressures are important indirect effects of coastal aquaculture on these islands.
\end{abstract}

KEY WORDS: Aquaculture - Seagrass - Posidonia oceanica Paracentrotus lividus $\cdot$ Nitrogen · Herbivory $\cdot$ Indirect effects

\section{INTRODUCTION}

Seagrass ecosystems are among the most productive (Duarte \& Chiscano 1999) and economically valuable (Costanza et al. 1997) on Earth and are found along the coasts of every continent except Antarctica. In the Mediterranean Sea, Posidonia oceanica (L.) Delile is the dominant seagrass species and is commonly found at depths shallower than $40 \mathrm{~m}$ (Boudouresque \& Meinesz 1982). This slow-growing monocot forms dense meadows or patches, which provide a myriad of ecosystem services (Duarte 2002). Although $P$. oceanica meadows once covered an area between 25000 and $45000 \mathrm{~km}^{2}$ throughout the Mediterranean Sea (Pasqualini et al. 1998), basin-wide declines of 5 to $20 \%$ have been estimated (Boudouresque et al. 2009). Furthermore, there is evidence of rapid declines in $P$. oceanica meadows at the regional scale (Marbà et al. 1996, 2005, Delgado et al. 1999, Duarte 2002). This loss has been largely a result of the cumulative effects of various anthropogenic influences, including increased aquaculture practices (Marbà et al. 2005, Pergent-Martini et al. 2006, Gonzalez-Correa et al. 2007).

Aquaculture has increased rapidly in the Mediterranean Sea over the last 3 decades (Karakassis et al. 
2000, Belias et al. 2003), and some of the largest expansions have occurred in the eastern portion. Production in Greece has increased by 2 orders of magnitude during that time to $114888 \mathrm{t} \mathrm{yr}^{-1}$ in 2008 (FAO 2009a). Since 2003, aquaculture production has surpassed wild fisheries production in Greece (FAO 2009b), and this trend will probably continue as wild fish populations decline and food demand increases (FAO 2010). Currently, Greece is the largest producer of cultured gilthead seabream Sparus aurata and seabass Dicentrarchus labrax in the European Union, with nearly 270 active fish farming operations (Belias et al. 2003). Although public sentiment remains ambivalent about aquaculture expansion in many coastal regions in Greece, economic benefits seem to overshadow environmental considerations, thus driving public acceptance of the practice (Katranidis et al. 2003).

Coastal fish farming practices use floating net pens stocked with predominantly carnivorous species that feed on dry pellet feeds. Uneaten food and fecal material pass directly through the nets into the surrounding environment, supplying organic matter and nutrients to the water column (Dalsgaard \& KrauseJensen 2006, Holmer et al. 2008) and surficial sediments (Wu 1995, Karakassis et al. 2000, Ruiz et al. 2001, Holmer et al. 2003, Apostolaki et al. 2007, DíazAlmela et al. 2008). Increased nutrient concentrations in the water column surrounding these fish farms are thought to be of less concern than their effects on sediments (Karakassis et al. 2005, Pitta et al. 2006), as they are rapidly assimilated into phytoplankton biomass and grazed by planktivores (Pitta et al. 2009). In the surrounding sediments, however, nutrients and organic matter can accumulate (Pusceddu et al. 2007), which can stimulate bacterial growth and increase benthic respiration (La Rosa et al. 2001, Vezzulli et al. 2002). This may lead to anoxic events and toxic porewater conditions for benthic organisms (Belias et al. 2003, Frederiksen et al. 2007, Holmer et al. 2008, Papageorgiou et al. 2009). These conditions can persist even after fish farming practices have ended (Delgado et al. 1999, Karakassis et al. 1999).

Coastal fish farming has been considered one of the largest sources of stress on seagrass ecosystems at the local scale in the Mediterranean Sea (Duarte 2002, Holmer et al. 2008). Direct effects of coastal fish farming on Posidonia oceanica meadows include altered sediment chemistry (Pusceddu et al. 2007), increased porewater toxicity (Frederiksen et al. 2007) and bacterially induced anoxic events (Lopez et al. 1998, Ruiz et al. 2001, Hyland et al. 2005, Pérez et al. 2007). Similarly, ambient light reduced through shading from net structures (Delgado et al. 1999, Pergent et al. 1999), effluent discharge (Ruiz et al. 2001) or nutrient-mediated epiphytic overgrowth (Delgado et al. 1999, Ruiz \& Romero 2001, Ruiz et al. 2001, Cancemi et al. 2003) also stress seagrasses.

Another factor affecting seagrass ecosystems near coastal fish farms in the Mediterranean Sea is intense herbivore grazing pressure (Tomas et al. 2005a, Prado et al. 2007a), which is enhanced around fish farms (Ruiz et al. 2001, 2009, Holmer et al. 2003). High densities of the sea urchin Paracentrotus lividus and the sparid fish Sarpa salpa can directly con-

Fig. 1. Study sites in Evia and Crete, Greece, indicating locations of impacted patches (0) and control seagrass patches (

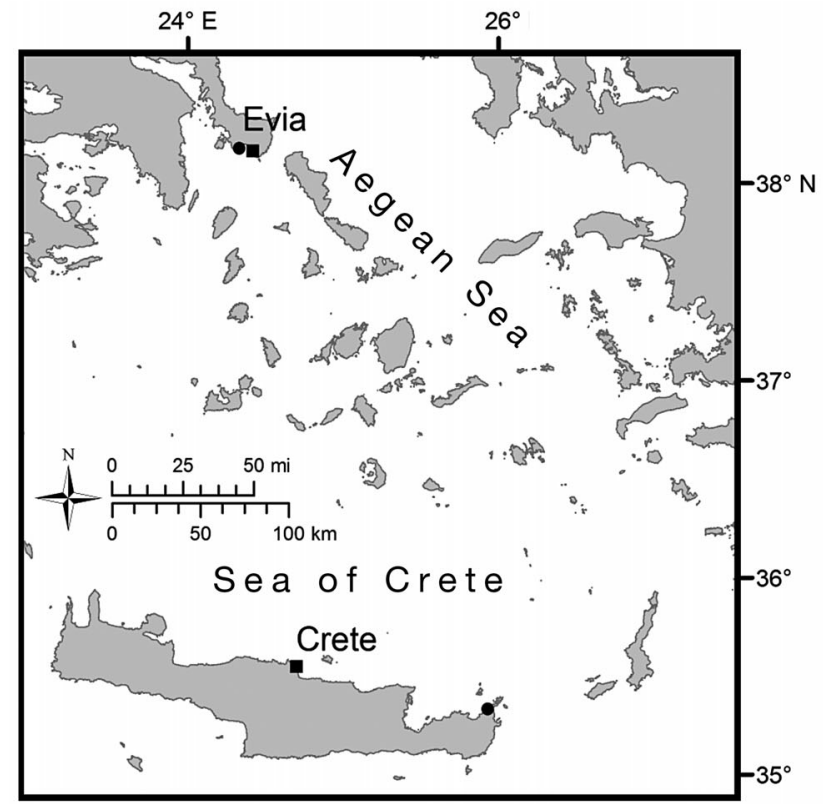


tribute to seagrass meadow decline and reduced productivity in meadows affected by cage culture (Ruiz et al. 2009). Understanding the various effects of coastal aquaculture on surrounding seagrass ecosystems is therefore vital in managing the continued practice and future expansion of this industry.

The effects of relatively large-scale fish farming operations on Posidonia oceanica meadows at depths $\geq 5 \mathrm{~m}$ have received considerable attention in the Mediterranean Sea (Pergent-Martini et al. 2006, Holmer et al. 2008). Much less research has evaluated the effects of smaller-scale operations on shallower ( 2 to $3 \mathrm{~m}$ ) seagrass patches found closer to the shore. Shallow patches are ecologically important as they are more productive (leaf and rhizome) and have higher shoot density per square meter (Pergent-Martini et al. 1994) than conspecifics in deeper meadows, while also providing substantial forage for herbivores (Tomas et al. 2005b). The objectives of this study were to evaluate the effects of both small-scale and largescale fish farm production on shoot morphometrics, productivity, sea urchin grazing pressure and nutrient content in shallow $P$. oceanica seagrass ecosystems. This research (1) examined seagrass shoot morphometrics and productivity between control seagrass patches and those affected by fish farming (impacted) on 2 Greek islands, (2) quantified sea urchin density and herbivore feeding pressure, (3) quantified epiphyte load across all patches and (4) evaluated nitrogen and carbon concentrations in seagrass and epiphyte tissues. These parameters were selected as they are commonly used (Pergent-Martini et al. 2005) and provide reliable means to evaluate the effects of aquaculture on the Mediterranean Sea.

\section{MATERIALS AND METHODS}

\section{Experimental design}

This study examined 4 monotypic and isolated patches of the seagrass Posidonia oceanica twice during February to May in 2008. Sampled seagrass patches were located in the coastal waters of 2 Greek islands, Evia and Crete (Fig. 1). On each island, one impacted seagrass patch and one control seagrass patch were sampled. Seagrass patches were isolated and no other seagrasses were in the visible vicinity $(\sim 50 \mathrm{~m})$, as assessed by SCUBA divers. Impacted seagrass patches were located near fish farms $(100 \mathrm{~m}$ southwest of cages in Evia and $200 \mathrm{~m}$ southeast of cages in Crete), while control seagrass patches were located far away $(7 \mathrm{~km}$ east of cages in Evia and
$100 \mathrm{~km}$ west of cages in Crete). All 4 sampled patches were selected based on their similarity in area $\left(\sim 12 \mathrm{~m}^{2}\right)$, depth ( 2 to $\left.3 \mathrm{~m}\right)$, distance from land $(\sim 4$ to $5 \mathrm{~m})$ and isolation from other patches or meadows. Although the control patch in Crete was much farther away from the impacted patch, it fulfilled the above requirements, as no other appropriate control patch was found in the same bay as the fish farm. Water temperature and salinity were measured and recorded during each sampling event by using SCUBA diver computers (Sherwood Profile Dive Computer) and hand-held refractometers (A. Krüss HR27-100).

\section{Study sites}

Seagrass patches were selected to ensure they were located in bays of similar coastal morphology and human development, in which there was no riverine input and seasonal tourism was modest. Aquaculture effluent was believed to be the only significant source of nutrient pollution to the impacted seagrass patches on both islands, where no major urban development was present within $1 \mathrm{~km}$. The Sitia fish farm (Crete) at the time of this study operated approximately 45 to 50 net cages and produced about $1000 \mathrm{t} \mathrm{yr}^{-1}$ of sea bass and gilthead seabream (Pitta et al. 2009). Cages were suspended above depths that ranged from 15 to $30 \mathrm{~m}$ over coarse to fine grain sand (Papageorgiou et al. 2009). In total, approximately $2000 \mathrm{t}$ of feed were released to farmed fish annually at this site (Pitta et al. 2009), which led to enriched water concentrations of dissolved inorganic nitrogen and phosphorus in the surrounding area (Pitta et al. 2006). In contrast, the fish farm in Karystos (Evia) was much smaller and had only 4 to 5 seasonally active net pens that produce about $75 \mathrm{t}$ $\mathrm{yr}^{-1}$ of mostly gilthead seabream and some sea bass. Cages were located over a depth of $15 \mathrm{~m}$.

\section{Granulometry and sediment organic matter}

For each sampling event, February/March and April/May, 4 sediment cores ( $4.5 \mathrm{~cm}$ inner diameter) were collected by SCUBA divers at each seagrass patch in Crete. One core was taken for analysis of the sediment grain size ( 0 to $5 \mathrm{~cm}$ depth), while the other cores were used for analysis of loss on ignition (LOI) organic matter at 0 to 1,1 to 3 , and 3 to $5 \mathrm{~cm}$ depths. Cores were taken $<0.5 \mathrm{~m}$ outside of the seagrass patch, at a depth of $\geq 15 \mathrm{~cm}$. Although we first 
attempted to obtain core samples inside seagrass patches, the core samplers could not penetrate to the proper depth. Collected sediment was extruded, sectioned and frozen. For granulometry samples, sediment was freeze-dried (Chemlab SB4) and passed through a series of sieves (Gray 1981). In April/May, only 2 cores were taken for LOI analysis in impacted and control patches. Samples for LOI analysis from each respective depth and from both sampling events were freeze-dried, massed for initial weight, combusted in ceramic crucibles in a muffle furnace (Nabertherm B170) at $500^{\circ} \mathrm{C}$ for $48 \mathrm{~h}$ and reweighed. The organic content of the sediment was recorded as the percent difference in mass between the initial dried sample and the combusted sample (Kristensen \& Andersen 1987).

\section{Seagrass productivity, morphometrics and epiphyte load}

Seagrass productivity was evaluated in all seagrass patches during both February/March and April/May sample periods, which corresponded to periods of low and high fish farm feeding rates, respectively (Papageorgiou et al. 2009). In each seagrass patch, 3 PVC rings (16.5 $\mathrm{cm}$ diameter) were haphazardly thrown by SCUBA divers. Rings that landed $<1 \mathrm{~m}$ from the seagrass patch's edge were excluded to eliminate potential edge effects. All shoots originating from inside the rings were marked for productivity analysis by using a modified seagrass marking technique (Alcoverro et al. 2000). Marked shoots were allowed to grow for at least 27 to $48 \mathrm{~d}$ before they were harvested. All shoots within each respective PVC ring were then placed into separate dive bags and returned to the lab for processing. Marked seagrass shoots were randomly selected from each dive bag for productivity measurements. Approximately 30 shoots $(3$ replicates of 10 per sampling date) were collected from each seagrass patch to estimate productivity in each patch.

For all shoots, after blades were rinsed and epiphytes were removed by gently scraping with a razor blade, total leaf length and width were measured to the nearest millimeter. All leaf material from the shoot base to the needle mark and newly germinated seagrass blades with no needle mark were considered to be new growth, while the remaining material was considered to be old growth. All new and old leaf biomasses were separated and freeze-dried before weighing. Epiphyte loads (mg epiphyte $\mathrm{g}^{-1}$ seagrass) were calculated by using shoots gathered indepen- dently from those collected for productivity measurements. During February/March sampling, SCUBA divers haphazardly collected 100 shoots from each seagrass patch (control and impacted) at both islands. Similarly, in April/May, 30 shoots were haphazardly collected from all patches. Shoots and epiphytes were processed and weighed following the procedures described above; however, epiphyte loads were not quantified for shoots collected during April/ May as seagrass biomass was not weighed.

\section{Nutrient content in leaves and epiphytes}

Total nitrogen and carbon content of seagrass blades and epiphytes were quantified during February/March for seagrass patches in Evia and Crete, corresponding with the time at which the highest $\mathrm{N}$ content is observed in Posidonia oceanica (Alcoverro et al. 2000). Dried seagrass biomass and epiphytes were pulverized into a fine powder, and total nitrogen and carbon were determined by oxidation in a Flash EA 1112 elemental analyzer (CE Instruments) following the methods of Atkinson \& Smith (1983).

\section{Sea urchin density and herbivore feeding pressure}

Seagrass shoot density (shoots $\mathrm{m}^{-2}$ ) and sea urchin density (ind. $\mathrm{m}^{-2}$ ) were estimated by means of benthic surveys, in which all shoots and urchins were counted within 5 replicate and haphazardly tossed $0.25 \mathrm{~m}^{2}$ quadrats. Quadrats were rejected if they landed within $0.5 \mathrm{~m}$ of the patch edge. Benthic surveys were conducted in all seagrass patches during February/March and April/May.

Herbivore feeding pressure was quantified by using shoots harvested for epiphyte load quantification. In the lab, harvested shoots were cut from rhizomes at the ligula and carefully cleaned of all epiphytes. Because both sea urchin Paracentrotus lividus and fish Sarpa salpa make species-specific grazing scars (Boudouresque \& Meinesz 1982), shoots could be scored into one of the following categories: no grazing scars (NG), sea urchin scars only $(\mathrm{U})$, fish scars only (F) and both sea urchin and fish scars (B). Herbivore feeding pressure was quantified on a per shoot basis by means of a modified grazing scar frequency method developed by Alcoverro et al. (1997), in which the total number in each scar category was divided by the total number of shoots examined. 
Table 1. Results of a 2-level nested ANOVA with 'Farming intensity/Island' (small-scale, Evia vs. large-scale, Crete) as a fixed factor nested within another fixed factor, 'Fish farming' (impacted patch versus control patch); $\mathrm{p}<0.05$ was considered significant. LOI: loss on ignition; SS: seagrass shoot. Transformation functions applied to data that did not meet assumptions of normality (Shapiro-Wilks test; level of significance, a, in parentheses) are shown

\begin{tabular}{|c|c|c|c|c|c|c|c|c|c|}
\hline \multirow[t]{2}{*}{ Variable } & \multicolumn{4}{|c|}{ — Farming intensity/Island — } & \multicolumn{4}{|c|}{$\longrightarrow$ Fish farming -} & \multirow{2}{*}{$\begin{array}{l}\text { Transfor- } \\
\text { mation (a) }\end{array}$} \\
\hline & df & MS & $F$ & $\mathrm{p}$ & $\mathrm{df}$ & MS & $F$ & $\mathrm{p}$ & \\
\hline LOI $(0-1 \mathrm{~cm})$ & & & & & 1 & 0.000 & 0.225 & 0.648 & $x^{2}(0.08)$ \\
\hline LOI $(3-5 \mathrm{~cm})$ & & & & & 1 & 0.005 & 1.064 & 0.333 & $-x^{-2}(0.24)$ \\
\hline Leaf length (mm) & 1 & 11.150 & 1.117 & 0.304 & 2 & 405.570 & 40.622 & $<0.0001$ & Ranks $^{\mathrm{a}}$ \\
\hline Leaf width (mm) & 1 & 0.302 & 1.537 & 0.230 & 2 & 3.108 & 15.805 & $<0.0001$ & $x(0.95)$ \\
\hline Epiphyte load (mg epiphyte $\mathrm{g}^{-1}$ grass) & 1 & 1963890.000 & 225.954 & $<0.0001$ & 2 & 479528.000 & 55.172 & $<0.0001$ & Ranks $^{\mathrm{a}}$ \\
\hline Total $N(\% N)$, leaf & 1 & 2.357 & 203.823 & $<0.0001$ & 2 & 0.335 & 28.997 & 0.0002 & $x(0.42)$ \\
\hline Total C (\%C), leaf & 1 & 0.070 & 0.282 & 0.610 & 2 & 4.326 & 17.505 & 0.001 & $x(0.89)$ \\
\hline Total N (\%N), epiphyte & 1 & 0.053 & 22.420 & 0.001 & 2 & 0.017 & 7.253 & 0.016 & $-x^{-1}(0.38)$ \\
\hline Total C (\% C), epiphyte & 1 & 0.000 & 29.198 & 0.001 & 2 & $<0.0001$ & 2.414 & 0.151 & $-x^{-2}(0.60)$ \\
\hline Seagrass density (shoots $\mathrm{m}^{-2}$ ) & 1 & 0.673 & 7.141 & 0.011 & 2 & 1.744 & 18.511 & $<0.0001$ & $x^{0.25}(0.36)$ \\
\hline
\end{tabular}

\section{Statistical analysis}

A 2-level nested analysis of variance (ANOVA) with 'Farming intensity/Island' (small-scale, Evia vs. large-scale, Crete) used as a fixed factor nested within another fixed factor, 'Fish farming' (impacted patch vs. control patch). Statistical analyses were conducted using $\mathrm{R}$ statistical software (CRAN R v. 2011.1, package stats, www.R-project.org/) at an $\alpha$ of 0.05. All data was analyzed for normality using a Shapiro-Wilk normality test prior to analysis. Data that did not meet assumptions of normality were transformed prior to analysis by using functions in Table 1. Data for leaf length ( $\mathrm{mm})$, urchin density (ind. $\mathrm{m}^{-2}$ ) and epiphyte load ( $\mathrm{mg} \mathrm{g}^{-1}$ seagrass) could not be transformed to pass normality tests and analyses were run on ranked data following Conover \& Iman (1981). Leaf length and epiphyte load failed to have equal variance $(p<0.05)$, while sea urchin density data passed tests of equal variance $(p=0.121)$. We acknowledge that the sampling design had limitations, as a result of having only sampled one control and one impacted patch on each island. As intraisland variability was not assessed in this study, significant differences between impacted and control patches and among islands were carefully interpreted. Table 1 contains a summary of our statistical analysis and significance levels for all variables.

\section{RESULTS}

\section{Study site parameters}

Water temperature and salinity measurements were similar between impacted and control patches on each island. While water temperatures at Evia and Crete ranged from 15 to $16^{\circ} \mathrm{C}$ in February/March, they rose to 19 and $20^{\circ} \mathrm{C}$, respectively, in April/May. Salinity values ranged from 38 to 40 in Evia and 40 to 41 in Crete during February/March, and decreased to $37 / 38$ and 38/39 psu, respectively, during April/May, presumably owing to increased precipitation.

Table 2. Sediment variables (mean \pm SD) for control and impacted Posidonia oceania patches at Crete. $\phi:$ Krumbein (1934) $\phi$ scale for grain size analysis

\begin{tabular}{|c|c|c|c|c|c|}
\hline \multirow[t]{2}{*}{ Seagrass } & \multirow[b]{2}{*}{$0-1 \mathrm{~cm}$ depth (mg) } & \multicolumn{2}{|l|}{ Loss on ignition (LOI) } & \multicolumn{2}{|c|}{ Granulometry } \\
\hline & & $1-3 \mathrm{~cm}$ depth (mg) & 3-5 cm depth (mg) & $\%$ coarse to fine sand $(4-2 \phi)$ & \% silt-clay \\
\hline Control & $0.012 \pm 0.001$ & $0.011 \pm 0.001$ & $0.011 \pm 0.001$ & $99.801 \pm 0.004$ & $0.199 \pm 0.004$ \\
\hline Impacted & $0.011 \pm 0.003$ & $0.012 \pm 0.000$ & $0.055 \pm 0.096$ & $99.867 \pm 0.135$ & $0.133 \pm 0.135$ \\
\hline
\end{tabular}


Granulometry and LOI data collected and analyzed for patches in Crete were similar between control and impacted seagrass patches. Both Cretan seagrass patches sampled had sediments composed almost entirely of fine sand $(4>\phi>2$ fraction, Table 2; Papageorgiou et al. 2009). Sediment organic content in the impacted seagrass patch was not significantly different (Table 1) compared with the control seagrass patch at any sediment depth analyzed (Table 2).

\section{Seagrass morphometrics, productivity and epiphyte load}

Seagrass shoots in impacted patches were significantly shorter and narrower (Table 1) than control patches at both islands (Fig. 2). Specifically, seagrass leaves were 2.8 and 4 times shorter and 0.8 and $1.25 \mathrm{~mm}$ narrower in impacted seagrass patches compared with control patches at Evia and Crete, respectively. Shoot productivity (mg shoot ${ }^{-1} \mathrm{~d}^{-1}$ ) was also significantly reduced in impacted patches (Table 1), and control patches exhibited 1.94 and 2.45 times greater productivity than impacted patches at Evia and Crete, respectively (Fig. 2). Epiphyte loads (mg epiphyte $\mathrm{g}^{-1}$ seagrass) were significantly greater
(Table 1) in impacted seagrass patches than in control patches on both islands during February/March, but this difference could not be attributed to fish farming as significant differences in epiphyte loads between islands were also found (Fig. 3).

\section{Nutrient content in leaves and epiphytes}

Nitrogen content of seagrass tissues were reduced in Evian seagrass patches compared with that in Cretan patches (Fig. 4). At both islands N content of seagrass tissues in the impacted patch were significantly greater than those in respective control seagrass tissues (Fig. 4), but this could not be specifically attributed to fish farming, as a significant island effect was found (Table 1). Leaf tissue carbon content, however, was significantly greater (Table 1) in impacted patches at both islands (Fig. 4). Ratios of carbon to nitrogen $(\mathrm{C}: \mathrm{N})$ were higher in control seagrass tissues examined compared with those from impacted seagrass patches at both islands. C:N ratios for seagrass tissues from Evian patches were higher than the respective Cretan seagrass patches (Table 3 ).

Nitrogen content in epiphytes tissues was significantly different between islands (Table 1), and this overshadowed the differences seen between seagrass patches (Fig. 4). Carbon content in epiphytes did not differ significantly between control and impacted seagrass patches at either island, but did differ significantly between islands (Table 1), and Evian epiphytes had lower carbon content than those in Cretan patches.

\section{Seagrass and sea urchin survey}
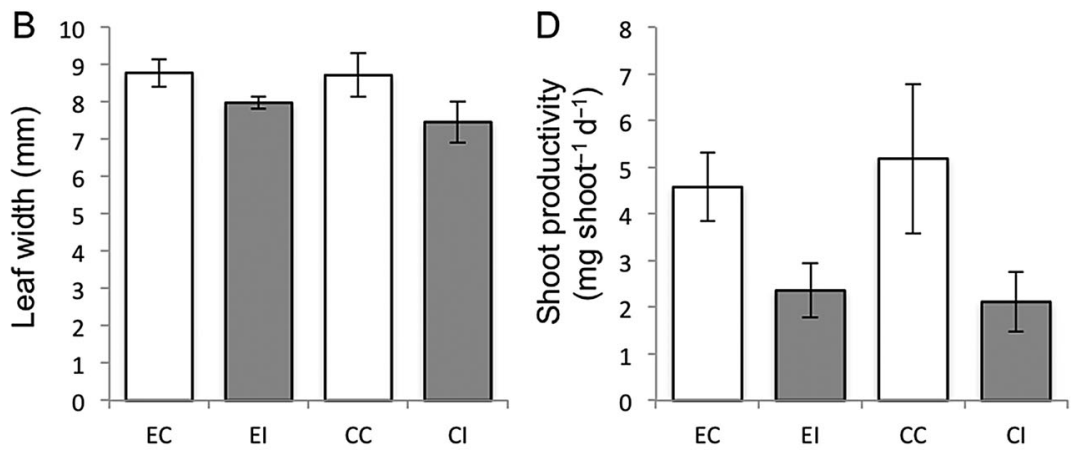

Fig. 2. Posidonia oceanica. Seagrass variables (mean $\pm \mathrm{SD}$ ) in control and impacted seagrass patches in Evia and Crete: (A) leaf length (mm), (B) leaf width $(\mathrm{mm}),(\mathrm{C})$ standing crop $\left(\mathrm{g}\right.$ shoot $\mathrm{m}^{-2}$ ) and (D) shoot productivity (mg shoot ${ }^{-1}$ $\mathrm{d}^{-1}$ ). EC: Evia control; EI: Evia impacted; CC: Crete control; CI: Crete impacted
Seagrass shoot density among all patches, islands and sampling events ranged from $272 \pm 72$ (mean \pm $\mathrm{SD})$ to $799 \pm 39$ shoots $\mathrm{m}^{-2}$. In Evia the control seagrass patch was denser than the impacted patch (Table 3) while in Crete, shoot density in the impacted patch was denser than the control patch. A significant difference in shoot density between islands was also found, suggesting that other factors besides fish farming may also be affecting seagrass density. 

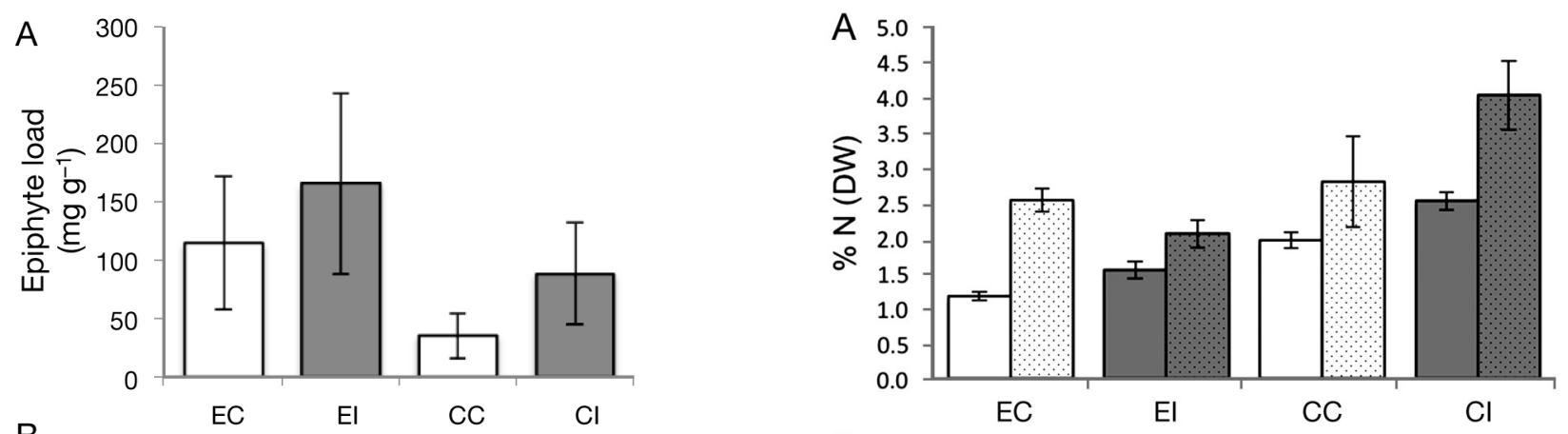
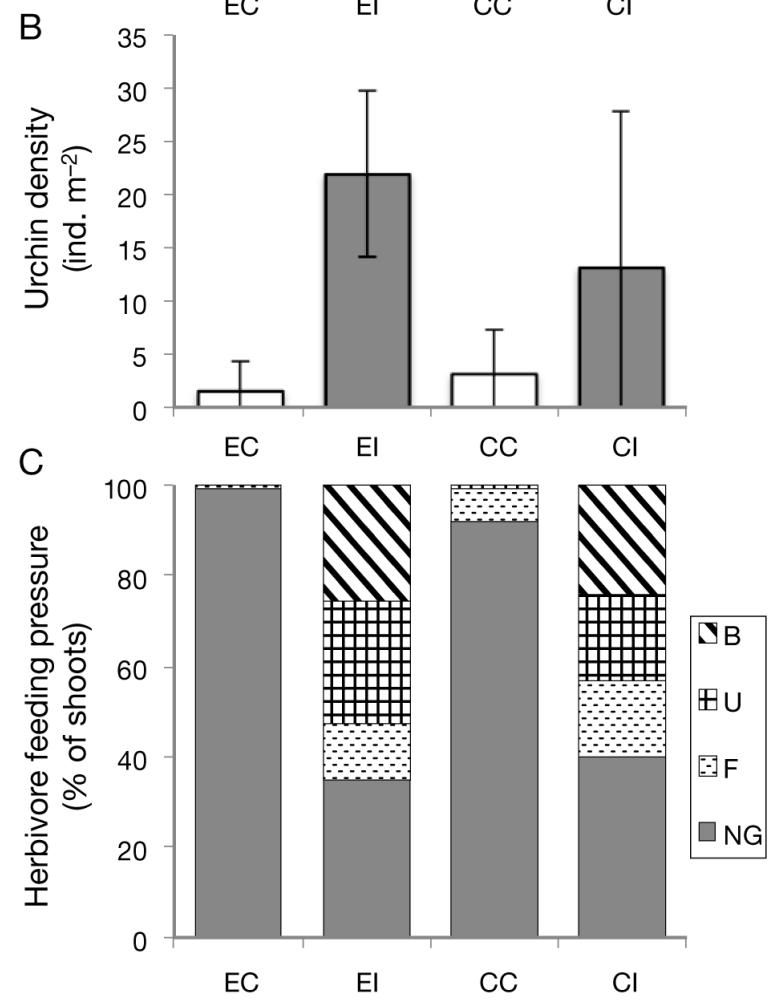

Fig. 3. Posidonia oceanica. (A) Mean \pm SD epiphyte load (mg dry weight $\mathrm{g}^{-1}$ ) in seagrass patches sampled in February/ March. (B) Mean sea urchin Paracentrotus lividus density \pm $\mathrm{SD}$ (ind. $\mathrm{m}^{-2}$ ). (C) Herbivore feeding pressure on seagrass shoots across seagrass patches. B: \% seagrass shoots with both fish and urchin grazing scars; U: \% seagrass shoots with at least one urchin grazing scar; F: \% seagrass shoots with at least one fish grazing scar; NG: \% shoots with no grazing scars. EC: Evia control; EI: Evia impacted; CC: Crete control; CI: Crete impacted

Paracentrotus lividus counts were consistently greater in impacted seagrass patches at both islands. Impacted patches at both Evia and Crete had significantly higher (Table 1) sea urchin densities (mean $=18 \pm 12$ ind. $\mathrm{m}^{-2}$, mode $=12$ ind. $\mathrm{m}^{-2}$, $\mathrm{n}=20$ ) than those in control patches (mean $=2 \pm$ 4 ind. $\mathrm{m}^{-2}$, mode $=0$ ind. $\mathrm{m}^{-2}, \mathrm{n}=20$ ) (Fig. 2). In control patches at both islands, $60 \%$ of surveyed quadrats had no sea urchins, while at least 1

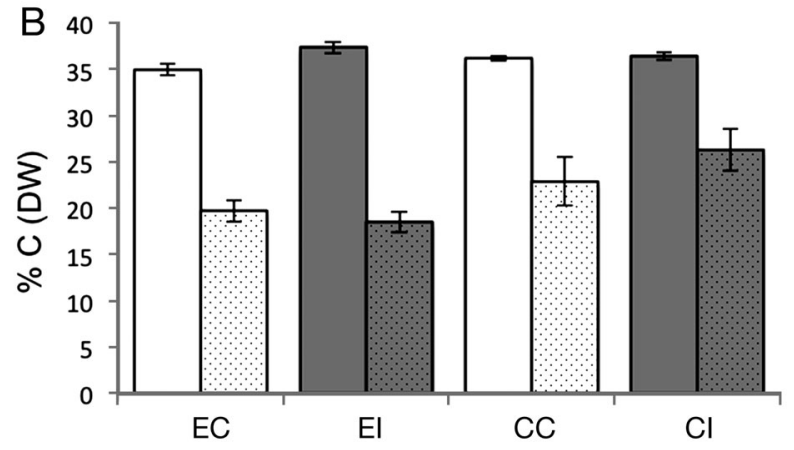

Fig. 4. Posidonia oceanica. Mean \pm SD tissue (A) N content (\% dry weight [DW]) and (B) C content (\% DW) for leaf (plain bars) and epiphyte (dotted bars) in control and impacted seagrass patches during February/March. EC: Evia control;

EI: Evia impacted; CC: Crete control; CI: Crete impacted

Table 3. Posidonia oceanica. Seagrass shoot density (mean \pm $\mathrm{SD}$ ) and carbon to nitrogen $(\mathrm{C}: \mathrm{N})$ nutrient ratios (mean \% DW) for leaf and epiphyte tissues in control and impacted seagrass patches at Evia and Crete

\begin{tabular}{|lccc|}
\hline Site & $\begin{array}{c}\text { Seagrass } \\
\text { shoot density } \\
\left(\text { shoots }^{-2} \text { ) }\right.\end{array}$ & $\begin{array}{c}\text { C:N ratio for } \\
\text { leaf tissue }\end{array}$ & $\begin{array}{c}\text { C:N ratio for } \\
\text { epiphyte tissue }\end{array}$ \\
\hline Evia & & & \\
Control & $666 \pm 169$ & 30.1 & 7.8 \\
Impacted & $407 \pm 76$ & 24.3 & 9.0 \\
Crete & & & \\
Control & $319 \pm 88$ & 18.5 & 8.2 \\
Impacted & $549 \pm 145$ & 14.8 & 6.5 \\
\hline
\end{tabular}

urchin was found in every replicated quadrat in impacted patches. Sea urchins were found at all strata of the seagrass ecosystem, and ranged from the upper canopy to the exposed rhizosphere.

\section{Herbivore feeding pressure}

Total herbivore feeding pressure (percentage of shoots with herbivore grazing scars) was low in control patches $(0.5 \%$ at Evia and $8 \%$ at Crete) while 
impacted patches at Evia and Crete had much higher values (65.5 and 60\%, respectively) (Fig. 2). Differences among specific categorical groups (sea urchin scar only, fish scar only, and both urchin and fish scar) were also observed. Sea urchin feeding pressure was greater than fish feeding pressure in impacted patches but not in control patches for both islands. Urchin feeding pressure in impacted patches accounted for 42 and $32 \%$ of the grazing scars found on shoots at Evia and Crete sites, respectively. When shoots that had scars from both sea urchins and fish were included, urchin scars were found on 53 and $43 \%$ of the shoots examined in impacted patches at Evia and Crete, respectively.

\section{DISCUSSION}

Coastal aquaculture is considered to be a significant threat to Posidonia oceanica conservation in the Mediterranean Sea (Pergent-Martini et al. 2006, Holmer et al. 2008). While research to elucidate the full effects of these operations is still in its infancy, previous efforts have focused on elucidating effects on seagrass meadows at depths $\geq 5 \mathrm{~m}$ in the vicinity of fish farm cages. Only a handful of studies have examined the potential effects on shallower seagrass meadows and patch communities (Delgado et al. 1997, 1999, Pergent et al. 1999, Ruiz et al. 2001), which are more productive (Pergent-Martini et al. 1994) and support higher herbivore densities (Tomas et al. 2005b, Prado et al. 2007a) than those at deeper depths. This study provides descriptive and correlative data to increase our understanding of the multiple effects that fish farms have on shallow seagrass patches. Our results demonstrate that substantial direct and indirect negative effects of aquaculture can be found in shallow seagrass patches adjacent to both large (Crete) and smaller (Evia) fish farming operations.

Seagrass patches sampled adjacent to fish farms on both islands were substantially degraded compared with control seagrass patches, as indicated by significantly reduced mean leaf length, width and productivity. Differences in leaf length between control and impacted patches on both islands in this study were comparable to those found in previous studies (Delgado et al. 1999, Dimech et al. 2002, Apostolaki et al. 2009), and control shoots were approximately 2 to 4 times longer than those in impacted patches. Shoot productivity was significantly lower in impacted patches compared with control patches at both islands (Fig. 2) and within or near ranges found by other studies in the Mediterranean Sea (2 to $4 \mathrm{mg}$ shoot $^{-1} \mathrm{~d}^{-1}$ in impacted seagrasses and 6 to $7.25 \mathrm{mg}$ shoot $^{-1} \mathrm{~d}^{-1}$ in control seagrasses (Ruiz et al. 2001, 2009). Shoot productivity was not significantly different between the islands, although true comparisons were not possible in the present study as the distance of impacted patches from the respective fish farms was not uniform, and bottom current velocity and water circulation were not monitored.

Sediment organic matter from LOI revealed no differences in sediments between control and impacted sites in the largest fish farm in this study (Crete). Previous studies that have examined sediments under and in close proximity to fish farm cages (0 to $40 \mathrm{~m}$ ) have revealed 2- to 4 -fold increases in organic matter (Karakassis et al. 2000, Ruiz et al. 2001), and enrichment of sediments decreased as distance from the fish farms increased. In our study, it was not surprising that organic enrichment of sediments was not found, as the impacted seagrass meadow in Crete was over $200 \mathrm{~m}$ away from fish cages. Although organic matter enrichment could not be detected in these sediments and increased epiphyte loads in impacted patches could not be attributed to fish farming, seagrasses seemed responsive to nutrient enrichment from fish farming activities, as $\mathrm{C}: \mathrm{N}$ ratios in leaf tissues from affected sites were lower than control tissues at both islands. Negative effects in impacted patches in this study seem to be more attributable to indirect factors such as increased herbivory compared with direct factors, although other stressors (e.g. porewater sulfide toxicity) cannot be definitively ruled out.

Impacted seagrass patches in this study had significantly higher densities of sea urchins compared with the respective control patches. Previous studies conducted at greater depths found similarly high sea urchin densities ranging from 11 to 50 ind. $\mathrm{m}^{-2}$ (Holmer et al. 2008, Ruiz et al. 2009) in impacted seagrass meadows. Sea urchin densities in our control patches were comparable with densities found in pristine seagrass patches and ranged from 0 to 6 ind. $\mathrm{m}^{-2}$ (Boudouresque \& Verlaque 2001). Not only were higher densities of urchins found in impacted patches, but urchin feeding pressure was considerably greater, and 53 and $43 \%$ of all shoots had at least one urchin scar at Evia and Crete, respectively. In control patches the feeding pressure was almost exclusively exerted by fish, and $0 \%$ of shoots had an urchin scar at Evia and only $1 \%$ at Crete.

Sea urchin populations in Mediterranean seagrasses are recruitment limited as evidenced by the lack of certain sized cohorts of the population (Tomas et al. 2004). Tomas et al. (2004) further suggested that 
urchin populations in healthy seagrass meadows are maintained by the migration of larger individuals from adjacent rocky areas. While the factors leading to urchin aggregations in impacted seagrass meadows are not fully understood, they may partially be a due to urchin attraction or migration toward increased organic matter in the vicinity of a cage or more abundant and palatable epiphyte food sources (Holmer et al. 2003, Balata et al. 2010). This is especially likely as $90 \%$ of the nitrogen assimilated by Paracentrotus lividus is derived from epiphyte food (Tomas et al. 2006) and sea urchins preferentially graze epiphytized seagrass leaves before consuming unepiphytized leaves (Boudouresque \& Verlaque 2001). In our study, we cannot definitively attribute observed higher epiphyte loads and enriched leaf tissue nitrogen content to fish farming, but it is likely a major contributor. Combining these factors may partially explain the significantly greater urchin densities and feeding pressures observed in impacted patches on both islands. Similar preferential grazing by herbivores on more palatable or nitrogen-rich plant material is not uncommon and has been documented for a variety of marine fauna (Bjorndal 1980, Boyer et al. 2004, Goecker et al. 2005, Tewfik et al. 2005).

Since intra-island variability in seagrass patches was not assessed in the present study, oceanographic conditions between waters surrounding the 2 islands or unknown natural or anthropogenic inputs in these regions may also be responsible for the increases in nitrogen content in seagrass and epiphyte tissues observed in these impacted sites. Additionally, taxonomic assessment of epiphyte communities in control and impacted patches was not undertaken in this study. Taxonomic differences in epiphyte communities also probably contribute to the observed increases in nitrogen content and palatability of epibiota (Balata et al. 2010) and may possibly explain the differences in nitrogen content of epiphyte tissues across patches and islands.

Sea urchins are a major structuring force in seagrass meadows of the Mediterranean Sea (Prado et al. 2007b); however, few studies have directly quantified urchin herbivory in seagrass patches affected by aquaculture. Ruiz et al. (2009) demonstrated that urchin grazing of aquaculture-influenced seagrasses effectively reduced areal coverage by $50 \%$ relative to caged exclusions. Although we did not perform a similar experiment to that of Ruiz et al. (2009), sea urchins in this study were commonly observed grazing in seagrass canopies of impacted seagrass patches at both islands, while this behavior was never observed in the taller seagrass canopies of control patches. Mechanical breakage due to increased epiphyte loading in nutrient enriched meadows (Leoni et al. 2006, 2008) and increased grazing (Ruiz et al. 2001, 2009) probably caused the reductions of leaf length observed in this study. Consequently, these shorter seagrass shoots had lower $\mathrm{C}: \mathrm{N}$ ratios and had greater epiphyte loads than control conspecifics. These factors may provide an explanation for the increased sea urchin density and increased feeding pressures observed in impacted patches, as the food material present is more dense, palatable and accessible.

Holmer et al. (2008) recommended a $400 \mathrm{~m}$ minimum operating distance for fish farming operations to avoid adversely affecting surrounding Posidonia oceanica ecosystems. These recommendations were based on relatively productive (260 to $1150 \mathrm{t} \mathrm{yr}^{-1}$ ) fish farms located far (500 to $2600 \mathrm{~m}$ ) from the shore (Holmer et al. 2008). The fish farms examined in the present study were substantially closer to shore $(<100 \mathrm{~m})$ and represented both large (Crete) and small (Evia) annual productions. Our results demonstrate that substantial degradation of Posidonia oceanica patches can occur regardless of the scale of fish farming intensity, and large declines were observed both $200 \mathrm{~m}$ from the Crete fish farm and $100 \mathrm{~m}$ from the Evia fish farm. Although a definitive safe operating distance cannot be proposed from our results, we emphasize the importance of proper zoning regardless of fish farming intensity. Further evaluation of the effects of small intensity aquaculture operations is warranted, especially as this has not been studied in great detail in the Mediterranean Sea.

In conclusion, this study presents evidence of the negative effects of fish farming on patches of the seagrass Posidonia oceanica in shallow water by demonstrating significant reductions in seagrass morphology and productivity in response to both large

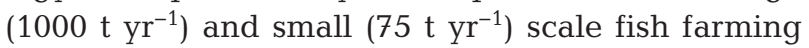
intensities. Aside from the direct negative effects of aquaculture on these seagrasses, we suggest that indirect effects can be equally as substantial to seagrass ecosystem health. Increased herbivore densities and feeding pressures in impacted patches at both islands suggest that grazing by sea urchins is probably enhanced indirectly by aquaculture effluent in Greece. Our results support the application of scientifically recommended zoning policies (Holmer et al. 2008) for coastal aquaculture regardless of production intensity to mitigate potential direct and indirect threats to surrounding seagrass ecosystems. 
Acknowledgements. A Fulbright Fellowship awarded to K.J.R. from the US Department of State and the Fulbright Foundation in Greece provided financial support for this research. The authors thank the fish farm staff on both islands for their support and gracious cooperation as well as Dikelas Dive Center and European Diving Institute. Special thanks go to E. T. Apostolaki, C. Chatzigeorgiou, S. Faulwetter, I. Kalantzi, N. Papageorgiou, C. Rempoulakis and K. Sigala for assistance with sampling and fruitful discussions. This manuscript was improved by the helpful comments of B. T. Furman, J. M. Carrol and 4 anonymous reviewers. The authors specifically thank B. T. Furman for help with statistical tests. This manuscript is dedicated in memory of Stavros and Kyriaki Rountos.

\section{LITERATURE CITED}

Alcoverro T, Duarte CM, Romero J (1997) The influence of herbivores on Posidonia oceanica epiphytes. Aquat Bot 56:93-104

> Alcoverro T, Manzanera M, Romero J (2000) Nutrient mass balance of the seagrass Posidonia oceanica: the importance of nutrient retranslocation. Mar Ecol Prog Ser 194: $13-21$

Apostolaki ET, Tsagaraki T, Tsapaki M, Karakassis I (2007) Fish farming impact on sediments and macrofauna associated with seagrass meadows in the Mediterranean. Estuar Coast Shelf Sci 75:408-416

Apostolaki ET, Marbà N, Holmer M, Karakassis I (2009) Fish farming enhances biomass and nutrient loss in Posidonia oceanica (L.) Delile. Estuar Coast Shelf Sci 81:390-400

> Atkinson MJS, Smith V (1983) C:N:P ratios of benthic marine plants. Limnol Oceanogr 28:568-574

> Balata D, Piazzi L, Nesti U, Bulleri F, Bertocci I (2010) Effects of enhanced loads of nutrients on epiphytes on leaves and rhizomes of Posidonia oceanica. J Sea Res 63: 173-179

Belias CV, Bikas VG, Dassenakis MJ, Scoullos MJ (2003) Environmental impacts of coastal aquaculture in eastern Mediterranean bays: the case of Astakos Gulf, Greece. Environ Sci Pollut Res Int 10:287-295

> Bjorndal KA (1980) Nutrition and grazing behavior of the green turtle Chelonia mydas. Mar Biol 56:147-154

Boudouresque CF, Meinesz A (1982) Decouverte de l'herbier de Posidonies. Cah Parc Natl Port-Cros 4:1-79

Boudouresque CF, Verlaque M (2001) Ecology of Paracentrotus lividus. In: Lawrence JM (ed) Edible sea urchins: biology and ecology, Vol 32. Elsevier Science, Amsterdam, p 177-216

> Boudouresque CF, Bernard G, Pergent G, Shili A, Verlaque M (2009) Regression of Mediterranean seagrasses caused by natural processes and anthropogenic disturbances and stress: a critical review. Bot Mar 52:395-418

Boyer KE, Fong P, Armitage AR, Cohen RA (2004) Elevated nutrient content of tropical macroalgae increases rates of herbivory in coral, seagrass, and mangrove habitats. Coral Reefs 23:530-538

> Cancemi G, De Falco G, Pergent G (2003) Effects of organic matter input from a fish farming facility on a Posidonia oceanica meadow. Estuar Coast Shelf Sci 56:961-968

Conover WJ, Iman RL (1981) Rank transformations as a bridge between parametric and nonparametric statistics. Am Stat 35:124-129

Costanza R, dArge R, deGroot R, Farber S and others (1997)
The value of the world's ecosystem services and natural capital. Nature 387:253-260

> Dalsgaard T, Krause-Jensen D (2006) Monitoring nutrient release from fish farms with macroalgal and phytoplankton bioassays. Aquaculture 256:302-310

Delgado O, Grau A, Pou S, Riera F, Massuti C, Zabala M, Ballesteros E (1997) Seagrass regression caused by fish cultures in Fornells Bay (Menorca, western Mediterranean). Oceanol Acta 20:557-563

> Delgado O, Ruiz J, Pérez M, Romero J, Ballesteros E (1999) Effects of fish farming on seagrass (Posidonia oceanica) in a Mediterranean bay: seagrass decline after organic loading cessation. Oceanol Acta 22:109-117

> Díaz-Almela E, Marbà N, Álvarez E, Santiago R and others (2008) Benthic input rates predict seagrass (Posidonia oceanica) fish farm-induced decline. Mar Pollut Bull 56: 1332-1342

Dimech M, Borg JA, Schembri PJ (2002) Changes in the structure of a Posidonia oceanica meadow and in the diversity of associated decapod, mollusc and echinoderm assemblages, resulting from inputs of waste from a marine fish farm (Malta, central Mediterranean). Bull Mar Sci 71:1309-1321

Duarte CM (2002) The future of seagrass meadows. Environ Conserv 29:192-206

Duarte CM, Chiscano CL (1999) Seagrass biomass and production: a reassessment. Aquat Bot 65:159-174

FAO (Food and Agriculture Organization of the United Nations) (2009a) Fishstat plus, aquaculture production data 1950-2008. FAO, Rome. Available at: www.fao.org/ fishery/statistics/software/fishstat/en (accessed 16 Feb 2010)

FAO (Food and Agriculture Organization of the United Nations) (2009b) Fishstat plus, capture fisheries data and aquaculture production data 1950-2009. FAO, Rome. Available at: www.fao.org/fishery/statistics/software/ fishstat/en (accessed 16 Feb 2010)

FAO (Food and Agriculture Organization of the United Nations) (2010) The state of world fisheries and aquaculture. FAO, Rome

> Frederiksen MS, Holmer M, Díaz-Almela E, Marbà N, Duarte CM (2007) Sulfide invasion in the seagrass Posidonia oceanica at Mediterranean fish farms: assessment using stable sulfur isotopes. Mar Ecol Prog Ser 345: 93-104

> Goecker ME, Heck KL, Valentine JF (2005) Effects of nitrogen concentrations in turtlegrass Thalassia testudinum on consumption by the bucktooth parrotfish Sparisoma radians. Mar Ecol Prog Ser 286:239-248

> Gonzalez-Correa JM, Sempere JTB, Sanchez-Jerez P, Valle C (2007) Posidonia oceanica meadows are not declining globally. Analysis of population dynamics in marine protected areas of the Mediterranean Sea. Mar Ecol Prog Ser 336:111-119

Gray J (1981) The sediment and related environmental factors. In: Barnes RSK, Miller PL, Paul J, Rees T (eds) The ecology of marine sediments. Cambridge University Press, Cambridge, p 11-19

Holmer M, Pérez M, Duarte CM (2003) Benthic primary producers - a neglected environmental problem in Mediterranean maricultures? Mar Pollut Bull 46:1372-1376

Holmer M, Argyrou M, Dalsgaard T, Danovaro R and others (2008) Effects of fish farm waste on Posidonia oceanica meadows: synthesis and provision of monitoring and management tools. Mar Pollut Bull 56:1618-1629 
Hyland J, Balthis L, Karakassis I, Magni P and others (2005) Organic carbon content of sediments as an indicator of stress in the marine benthos. Mar Ecol Prog Ser 295: 91-103

Karakassis I, Hatziyanni E, Tsapakis M, Plaiti W (1999) Benthic recovery following cessation of fish farming: a series of successes and catastrophes. Mar Ecol Prog Ser 184: 205-218

Karakassis I, Tsapakis M, Hatziyanni E, Papadopoulou KN, Plaiti W (2000) Impact of cage farming of fish on the seabed in three Mediterranean coastal areas. ICES J Mar Sci 57:1462-1471

Karakassis I, Pitta P, Krom MD (2005) Contribution of fish farming to the nutrient loading of the Mediterranean. Sci Mar 69:313-321

Katranidis S, Nitsi E, Vakrou A (2003) Social acceptability of aquaculture development in coastal areas: the case of two Greek islands. Coast Manag 31:37-53

Kristensen E, Andersen FO (1987) Determination of organic carbon in marine sediments: a comparison of two CHNanalyzer methods. J Exp Mar Biol Ecol 109:15-23

Krumbein WC (1934) Size frequency distribution of sediment. J Sediment Petrol 4:65-77

La Rosa T, Mirto S, Mazzola A, Danovaro R (2001) Differential responses of benthic microbes and meiofauna to fishfarm disturbance in coastal sediments. Environ Pollut 112:427-434

> Leoni V, Pasqualini V, Pergent-Martini C, Vela A, Pergent G (2006) Morphological responses of Posidonia oceanica to experimental nutrient enrichment of the canopy water. J Exp Mar Biol Ecol 339:1-14

> Leoni V, Vela A, Pasqualini V, Pergent-Martini C, Pergent G (2008) Effects of experimental reduction of light and nutrient enrichments ( $\mathrm{N}$ and $\mathrm{P}$ ) on seagrasses: a review. Aquat Conserv 18:202-220

> Lopez NI, Duarte CM, Vallespinos F, Romero J, Alcoverro T (1998) The effect of nutrient additions on bacterial activity in seagrass (Posidonia oceanica) sediments. J Exp Mar Biol Ecol 224:155-166

- Marbà N, Duarte CM, Cebrián J, Gallegos ME, Olesen B, Sand-Jensen K (1996) Growth and population dynamics of Posidonia oceanica on the Spanish Mediterranean coast: elucidating seagrass decline. Mar Ecol Prog Ser 137:203-213

Marbà N, Duarte CM, Díaz-Almela E, Terrados J and others (2005) Direct evidence of imbalanced seagrass (Posidonia oceanica) shoot population dynamics in the Spanish Mediterranean. Estuaries 28:53-62

Papageorgiou N, Sigala K, Karakassis I (2009) Changes of macrofaunal functional composition at sedimentary habitats in the vicinity of fish farms. Estuar Coast Shelf Sci 83: 561-568

> Pasqualini V, Pergent-Martini C, Clabaut P, Pergent G (1998) Mapping of Posidonia oceanica using aerial photographs and side scan sonar: application off the island of Corsica (France). Estuar Coast Shelf Sci 47:359-367

Pérez M, Invers O, Ruiz JM, Frederiksen MS, Holmer M (2007) Physiological responses of the seagrass Posidonia oceanica to elevated organic matter content in sediments: an experimental assessment. J Exp Mar Biol Ecol 344:149-160

Pergent G, Mendez S, Pergent-Martini C, Pasqualini V (1999) Preliminary data on the impact of fish farming facilities on Posidonia oceanica meadows in the Medi- terranean. Oceanol Acta 22:95-107

Pergent-Martini C, Rico-Raimondino V, Pergent G (1994) Primary production of Posidonia oceanica in the Mediterranean basin. Mar Biol 120:9-15

Pergent-Martini C, Leoni V, Pasqualini V, Ardizzone GD and others (2005) Descriptors of Posidonia oceanica meadows: use and application. Ecol Indic 5:213-230

Pergent-Martini C, Boudouresque CF, Pasqualini V, Pergent G (2006) Impact of fish farming facilities on Posidonia oceanica meadows: a review. Mar Ecol 27:310-319

Pitta P, Apostolaki ET, Tsagaraki T, Tsapakis M, Karakassis I (2006) Fish farming effects on chemical and microbial variables of the water column: a spatio-temporal study along the Mediterranean Sea. Hydrobiologia 563:99-108

> Pitta P, Tsapakis M, Apostolaki ET, Tsagaraki T, Holmer M, Karakassis I (2009) 'Ghost nutrients' from fish farms are transferred up the food web by phytoplankton grazers. Mar Ecol Prog Ser 374:1-6

Prado P, Alcoverro T, Martinez-Crego B, Verges A, Pérez M, Romero J (2007a) Macrograzers strongly influence patterns of epiphytic assemblages in seagrass meadows. J Exp Mar Biol Ecol 350:130-143

> Prado P, Tomas F, Alcoverro T, Romero J (2007b) Extensive direct measurements of Posidonia oceanica defoliation confirm the importance of herbivory in temperate seagrass meadows. Mar Ecol Prog Ser 340:63-71

> Pusceddu A, Fraschetti S, Mirto S, Holmer M, Danovaro R (2007) Effects of intensive mariculture on sediment biochemistry. Ecol Appl 17:1366-1378

Ruiz JM, Romero J (2001) Effects of in situ experimental shading on the Mediterranean seagrass Posidonia oceanica. Mar Ecol Prog Ser 215:107-120

Ruiz JM, Pérez M, Romero J (2001) Effects of fish farm loadings on seagrass (Posidonia oceanica) distribution, growth and photosynthesis. Mar Pollut Bull 42:749-760

Ruiz JM, Pérez M, Romero J, Tomas F (2009) The importance of herbivory in the decline of a seagrass (Posidonia oceanica) meadow near a fish farm: an experimental approach. Bot Mar 52:449-458

Tewfik A, Rasmussen JB, McCann KS (2005) Anthropogenic enrichment alters a marine benthic food web. Ecology 86 : 2726-2736

> Tomas F, Romero J, Turon X (2004) Settlement and recruitment of the sea urchin Paracentrotus lividus in two contrasting habitats in the Mediterranean. Mar Ecol Prog Ser 282:173-184

Tomas F, Turon X, Romero J (2005a) Effects of herbivores on a Posidonia oceanica seagrass meadow: importance of epiphytes. Mar Ecol Prog Ser 287:115-125

Tomas F, Turon X, Romero J (2005b) Seasonal and smallscale spatial variability of herbivory pressure on the temperate seagrass Posidonia oceanica. Mar Ecol Prog Ser 301:95-107

Tomas F, Alvarez-Cascos D, Turon X, Romero J (2006) Differential element assimilation by sea urchins Paracentrotus lividus in seagrass beds: implications for trophic interactions. Mar Ecol Prog Ser 306:125-131

> Vezzulli L, Chelossi E, Riccardi G, Fabiano M (2002) Bacterial community structure and activity in fish farm sediments of the Ligurian Sea (western Mediterranean). Aquac Int 10:123-141

Wu RSS (1995) The environmental impact of marine fish culture: towards a sustainable future. Mar Pollut Bull 31: 159-166

Submitted: June 8, 2011; Accepted: December 22, 2011

Proofs received from author(s): January 24, 2012 